\title{
TINJAUAN TEKSTUAL MUFASSIR NUSANTARA TENTANG PERLINDUNGAN HAK-HAK BURUH DI INDONESIA
}

\author{
Muhammad Bachrul Ulum ${ }^{1}$ \\ ${ }^{1}$ Universitas Islam Negeri (UIN) Sunan Kalijaga, Yogyakarta, Indonesia, e-mail: ulumbangsal@gmail.com

(c)2020 by the authors. Submitted for possible open access publication under the terms and conditions of the Creative Commons
Attribution-ShareAlike 4.0 International License-(CC-BY-SA) (https://creativecommons.org/licenses/by-sa/4.0/)
do $D O I: \underline{\text { http://dx.doi.org/10.30983/it.v4i2.3612 }}$
\begin{tabular}{|c|c|c|}
\hline Diterima: 16 Oktober 2020 & Direvisi : 20 Desember 2020 & Diterbitken: 31 Desember 2020 \\
\hline
\end{tabular}

\begin{abstract}
This research discusses the local ulama's interpretation of the verses of the Qur'an, which textually supports the optimization of the fulfillment of the rights of workers in Indonesia. The mufassirs are Prof. Quraish Shibab, Shaykh Nawawi Al-Jawi, and KH. Bisri Musthofa. Mufassir Nusantara bas a crucial role as a mediator between local communities who issue legal products and the Koran text, which is the absolute decree of Allah SWT to bumanity. This includes being a figure capable of providing Quranic solutions to various prophetic problems in society, including labor. This research is a literature study. The methodology used in this research is a qualitative research method by trying to dissect Mufassir Nusantara's thoughts against the texts of the AlQuran. The researcher found that the interpretation of the local Mufassir has relevance to the study of the text of the Al-Quran verses, which are used as the basis of arguments for the fulfillment of labor rights in Indonesia.
\end{abstract}

Keywords : Labor; The Local's mufassirs; Textualits tafsir.

\begin{abstract}
Abstrak
Penelitian ini membahas penafsiran ulama nusantara terhadap ayat -ayat Al-Qur'an yang secara tekstualitas mendukung optimalisasi pemenuhan hak- hak kaum buruh di Indonesia. Para Mufassir tersebut adalah Prof. Quraish Shihab, Syaikh Nawawi Al-Jawi, dan KH. Bisri Musthofa. Mufassir Nusantara memiliki peran yang krusial sebagai mediator antara masyarakat lokal yang mengeluarkan produk hukum, dengan teks Al-Quran yang merupakan ketetapan absolut Allah SWT kepada umat manusia. Termasuk diantaranya menjadi tokoh yang mampu memberi solusi Qurany terhadap berbagai problem profetik masyarakat, diantaranya buruh. Penelitian ini merupakan studi pustaka. Metodologi yang digunakan dalam penelitian ini adalah metode penelitian kualitatif, dengan mencoba membedah pemikiran Mufassir Nusantara terhadap teks -teks Al-Quran. Peneliti menemukan bahwa penafsiran Mufassir lokal memiliki relevansi terhadap studi teks ayat-ayat Al-Quran yang digunakan sebagai dasar argumentasi pemenuhan hak -hak buruh di Indonesia.
\end{abstract}

Kata Kunci : Buruh; Mufassir Nusantara; Tafsir Tekstual.

\section{Latar Belakang}

Dalam studi Al-Quran, tafsir merupakan salah satu produk analisis terhadap ayat- ayat Al-Qur'an, karena secara dzatiyah pun Al-Quran adalah kitab yang memancar darinya aneka ilmu keislaman dan mendorong untuk melakukan pengamatan dan penelitian ${ }^{1}$. Secara etimologi,

\footnotetext{
${ }^{1}$ M. Quraish Shihab, Kaidah Tafsir (Jakarta: Lentera Hati Group, 2013), 5.

2 Muhammad Husain Adz-Dzahabi, At-Tafsir wa Al-Mufassirun, Juz I., (Beirut: Dar al-Fikr, 2000), 323.
}

Tafsir memiliki makna الايضـاح و البيان (sebuah penjelasan), الكثف (pembedahan), كشف المر اد عن البضاح (sebe اللفظ (penguraian maksud dari sebuah lafadz)2. Sedangkan secara terminologis, Tafsir merupakan penjelasan terhadap Kalamullah atau menjelaskan lafadz-lafadznya serta pemahamannya ${ }^{3}$. Al-Quran tidak akan pernah

${ }^{3}$ Abdul Hamid Al-Bilali, Al-Mukhtashar Al-Mahsun li Kitab Al-Tafsir wa Al-Mufassirun (Kuwait: Darul Dakwah, 1405 H), 8. 
mempu dimanfaatkan secara maksimal sebagai pedoman hidup bagi manusia, jika pemahaman terhadapnya pun masih parsial. Maka munculnya karya-karya tafsir merupakan upaya para Mufassir untuk memberikan sumbangsih terhadap peradaban manusia.

Al-Quran sebagai referensi utama dalam Islam, sudah seharusnya dimanfaatkan secara maksimal untuk menunjang kehidupan manusia dalam kondisi apapun, termasuk dalam melindungi hak-hak konvensional umat Islam sebagai bagian dari peradaban manusia. AlQuran selain merupakan referensi hidup secara spiritual, juga merupakan referensi untuk menjawab persoalan-persoalan manusia di belahan dunia manapun, di era kapanpun. Diantaranya, Al-Quran dapat dijadikan sebagai referensi untuk menumbuhkan sumbangsih pemikiran yang relevan terhadap kehidupan kaum buruh. Islam memandang buruh sebagai pekerjaan yang mempunyai strata kemuliaan yang sama dengan pekerjaan yang lain, selama buruh bekerja di perusahaan atau tempat yang melakuakan transaksi secara halal. Dalam lintasan sejarah, Islam adalah agama yang memperhatikan ketimpangan stratifikasi sosial secara serius. Islam mengikis sedikit demi sedikit praktek perbudakan yang sangat umum terjadi di masyarakat Arab yang saat itu terbagi dalam berbagai kabilah dan suku, sehingga memunculkan pengkastaan sosial yang sangat kuat $^{4}$.

Kepedulian terhadap pemenuhan hak-hak buruh harus selalu dikawal secara berkala, karena kasus pelanggarannya. Kendati Indonesia adalah negara yang meregulasi buruh secara hukum dengan cukup baik, namun itu tidak menjamin ketiadaan kasus pelanggaran hak buruh. satu diantaranya adalah kasus yang

\footnotetext{
${ }^{4}$ Isnaini Harahap, Hadis-Hadis Ekonomi (Jakarta: Prenada Media, 2017), 71.

5 Aisha Amelia Yasmin, Ika Krismantari, and Nashya Tamara, "Kasus Aice: Dilema Buruh Perempuan di Indonesia dan Pentingnya Kesetaraan Gender di Lingkungan Kerja," The Conversation, accessed
}

terjadi pada Elitha Tri Novianty, seorang buruh wanita di PT. Alpen Food Industri yang pada tahun 2019 terpaksa harus melakukan operasi angkat rahim karena perusahaannya mengabaikan riwayat kesehatannya yang sedang hamil. Tidak hanya itu, tak kurang dari 15 buruh wanita juga mengalami keguguran dikarenakan hal tersebut ${ }^{5}$. Hal ini tentu melanggar pasal 73 UU no.13 tahun 2013 yang meregulasi soal buruh wanita.

Pilihan akan adanya referensi tafsir dari berbagai kalangan semakin hari semakin bervariasi, tak hanya dari Negara-Negara Arab, tapi juga dari Negara-Negara 'Ajam, tak terkecuali Indonesia. Tafsir lokal Indonesia memberikan warna tersendiri dalam dunia Tafsir, karena tentunya perbedaan budaya dan bahasa yang sangat mencolok antara tempat turunnya Al-Quran, yakni Negara Arab dengan Indonesia ${ }^{6}$.

Cendekiawan lokal Nusantara, termasuk diantaranya adalah Mufassir lokal Nusantara merupakan tokoh yang mendapat kepercayaan masyarakat. Tidak hanya dalam urusan agama, tapi juga secara sosial. Mereka dianggap mempunyai kemampuan untuk memberikan solusi atas segala permasalahan yang dihadapi masyarakat, karena dianggap memiliki pemahaman yang cukup valid tentang maksud Al-Quran. Maka secara tidak langsung, Mufassir Nusantara merupakan mediator antara Allah melalui KalamNya, dengan Masyarakat. Sehingga orang pertama yang akan dituju untuk dimintai pendapatnya ketika seseorang mempunyai masalah sosial adalah para Mufassir ini, tak terkecuali masalah - masalah yang terjadi dalam profesinya, termasuk diantaranya buruh.

December 26, 2020, http:/ / theconversation.com/kasusaice-dilema-buruh-perempuan-di-indonesia-danpentingnya-kesetaraan-gender-di-lingkungan-kerja133010.

6 Anggi Wahyu Wahyu Ari, "Sejarah Tafsir Nusantara," Jurnal Studi Agama 3, no. 2 (2019): 116. 
Dalam beberapa penelitian terdahulu, Qomar $^{7}, \quad$ Pratiwi $^{8}$, dan Hendrastomo $^{9}$ mengungkapkan bahwa akar permasalahan dalam kasus-kasus pelanggaran hak buruh selama ini adalah pengusaha menganggap buruh adalah salah satu faktor produksi yang harus ditekan biayanya untuk menghasilkan keuntungan finansial yang lebih banyak. Hal ini menyebabkan pengusaha mengabaikan status buruh sebagai manusia biasa yang punya hakhak asasi. Peran agama dalam perjuangan hakhak kaum bawah dikemukakan Fatkhul Muin, bahwa penafsiran Al-Quran juga harus responsive terhadap unsur sosio-kultural yang terjadi secara riil di masyarakat ${ }^{10}$. Sistem ekonomi yang dicita-citakan Al-Quran, sudah sepatutnya berbeda dengan sistem kapitalisme maupun sosialisme. Sistem kapitalisme menganggap buruh sebagai pekerja, dan majikan sebagai pemberi pekerjaan. Sehingga kelas sosialnya sangat jelas siapa yang diatas dan siapa yang dibawah. Hal ini tentu memberi dampak yang sangat besar terhadap potensi penyalahgunaan wewenang, dan kurang dipenuhinya hak si buruh. sedangkan dalam paham sosialisme sebaliknya, pihak buruh dianggap pihak paling dirugikan sehingga melakukan perlawanan secara besar-besaran terhadap kaum kapitalis.

Islam mencita-citakan prinsip etbical economy, sebuah prinsp ekonomi yang adil, memberikan win win solution baik untuk pengusaha maupun pekerja. Islam tidak menentang kekayaan seperti orang-orang sosialis, tapi juga tidak membiarkan kesewenang-wenangan para

${ }^{7}$ Moh Nurul Qomar, "Kritik Karl Marx Terhadap Konsep Buruh Kapitalis Kajian Komparatif Ekonomi Syariah Atas Buku Das Kapital I," in Proceedings of Annual Conference for Muslim Scholars, vol. 3 (2019); 1008.

${ }^{8}$ Dessy Fitri Pratiwi, Hadiyanto A. Rachim, and Rudi Saprudin Darwis, "Keberfungsian Sosial Buruh Perempuan pada Sektor Industri dalam Keluarga," Prosiding Penelitian dan Pengabdian Kepada Masyarakat 2, no. 2 (2015): 293.

9 Grendi Hendrastomo, "Menakar Kesejahteraan Buruh: Memperjuangkan Kesejahteraan Buruh diantara kapitalis. Islam meilih jalan keadilan, sebagaimana difirmankan Allah bahwa kita harus menjadi umat yang wasathan (moderat) ${ }^{11}$. Sehingga, selain unsur ekonomi, Islam juga mengedepankan unsur kemanusiaan yang menjadi salah satu komponen penggeraknya.

Penelitian ini merupakan studi kepustakaan (Library Research) yakni suatu studi kepustakaan yang mengumpulkan informasi dan data dengan bantuan berbagai macam material yang ada di perpustakaan seperti dokumen, buku, majalah, kisah-kisah sejarah, dsb ${ }^{12}$ metode yang digunakan adalah metode penelitian kualitatif, dikarenakan penelitian ini bertujuan untuk menghasilkan informasi berupa catatan dan data deskriptif. Selain itu kacamata yang digunakan dalam penelitian ini adalah ideologis-dogmatis karena merupakan kajian teks, namun tidak menghilangkan unsur sosio-kultural sebagai bahan pertimbangan penelitian.

Dengan demikian, penelitian ini akan fokus pada argumen penafsiran Mufassir Nusantara terhadap analisis tekstual ayat -ayat Al-Quran yang relevan dengan hak-hak buruh di Indonesia. Peneliti akan memaparkan ayat -ayat yang sesuai dengan hak-hak buruh, untuk kemudian dianalisis secara leksikal dan gramatikal, kemudian menunjukkan poin-poin relevansi Tafsir Nusantara terhadap analisis tersebut

\section{Buruh dan Perlindungannya dalam Perspektif Islam}

Dalam Kamus Besar Bahasa Indonesia (KBBI), Buruh didefinisikan sebagai orang yang bekerja untuk orang lain dengan mendapatkan

Kepentingan Negara dan Korporasi," Jurnal Informasi 16, no. 2 (2010): 15

10 Fatkhul Mubin, "Tafsir Emansipatoris: Pembumian Metodologi Tafsir Pembebasan," Mumtaæ: Jurnal Studi Al-Quran dan Keislaman 3, no. 1 (2019): 134.

${ }^{11}$ Fuad Riyadi, "Sistem dan Strategi Pengupahan Perspektif Islam,” Iqtishadia 8, no. 1 (2015): 168.

12 Abdi Mirzaqon T, "Studi Kepustakaan Mengenai Landasan Teori dan Praktik Konseling Expressive Writing," Jurnal BK Unesa 8, no. 1 (2017): 3. 
upah $^{13}$. Sedangkan Menurut UU No 13 Tahun 2003 tentang ketenagakerjaan Bab 1 Pasal 1, tenaga kerja adalah setiap orang yang mampu melakukan pekerjaan guna menghasilkan barang dan atau jasa baik untuk memenuhi kebutuhan sendiri maupun untuk masyarakat ${ }^{14}$. Saat ini, ada 2 istilah yang beredar di masyarakat, yakni istilah pekerja dan buruh. menurut KBBI kedua kata tersebut adalah sinonimi, alias memiliki arti yang serupa. Sebagai perbandingan, di zaman kolonial istilah buruh digunakan untuk pekerja kasar, seperti kuli panggul, tukang bangunan, dsb. Saat itu, ada 2 istilah untuk pekerja, yakni blue collar (kerah biru) sebutan bagi para pekerja kasar, dan white collar (kerah putih) bagi pekerja kantoran, administrasi, dan sejenisnya ${ }^{15}$.

Istilah "pekerja" kini lebih masif digunakan dalam administrasi perundang undangan nasional, dikarenakan kurang cocoknya istilah "buruh" dengan kepribadian bangsa yang seakan-akan masih dikekang pihak lain. istilah pekerja dianggap lebih relevan dengan kepribadian bangsa kita yang gemar bekerja. Istilah pekerja pertama kali digunakan pada UU no 25 tahun 1997 tentang ketenagakerjaan.

Islam memandang buruh sebagai pekerjaan yang mempunyai strata kemuliaan yang sama dengan pekerjaan yang lain, selama buruh bekerja di perusahaan atau tempat yang melakuakan transaksi secara halal. Dalam lintasan sejarah, Islam adalah agama yang memperhatikan ketimpangan stratifikasi sosial secara serius. Islam mengikis sedikit demi sedikit praktek perbudakan yang sangat umum terjadi di masyarakat Arab yang saat itu terbagi dalam berbagai kabilah dan suku, sehingga memunculkan pengkastaan sosial yang sangat kuat $^{16}$.

13 "KBBI Daring," accessed December 26, 2020, https://kbbi.kemdikbud.go.id/Error.htm?aspxerrorpath $=/$ entri/buruh

14 Tim Penyusun, UU No 13 Tabun 2003 tentang Ketenagakerjaan (Jakarta: Media Press, 2005), 12.

\section{Hak-hak Buruh di Indonesia}

Sebagaiamana tertuang dalam amanah undang-undang no 13 tahun 2003 tentang ketenagakerjaan, Pekerja atau buruh memiliki beberapa hak yang harus dipenuhi oleh majikan atau pengusaha. Diantaranya adalah; (1) Pasal 5 dan 6, hak untuk memperoleh kesempatan dan perlakuan yang sama tanpa diskriminasi; (2) Pasal 11 dan 12, Hak untuk memperoleh peningkatan dan pengembangan kompetensi serta mengikuti pelatihan; (3) Pasal 31, Hak dan kesempatan yang sama untuk memilih, mendapatkan, atau pindah pekerjaan; (4) Pasal 50 s.d Pasal 66, Hak atas kepastian dalam hubungan kerja; (5) Pasal 77 s.d Pasal 85, Hak atas waktu kerja, waktu cuti, kerja lembur, dan upah kerja lembur; (6) Pasal 88 s.d Pasal 101, Hak berkaitan dengan pengupahan, jaminan sosial, dan kesejahteraan; (8) Pasal 86 s.d Pasal 87, Hak mendapat perlindungan keselamatan dan kesehatan kerja, moral dan kesusilaan, serta perlakuan yang sesuai dengan harkat dan martabat manusia, serta hak memperoleh jaminan kematian akibat kecelakaan kerja; (9) Pasal 104, Hak berorganisasi dan berserikat; (10) Pasal 137 s.d Pasal 145, Hak mogok kerja; (11) Pasal 156, Hak uang pesangon setelah Pemutusan Hubungan Kerja (PHK)'

Dari kesekian banyak hak-hak buruh, kita bisa ambil garis besar bahwa hak-hak dasar buruh dibagi menjadi 3 kategori besar, yaitu; pertama adalah Hak atas upah yang layak. Sebelum memulai hubungan kerja, tentunya ada kesepakatan resmi antara pengusaha dengan pekerja tentang apa yang harus pekerja berikan pada bos (kewajiban) dan apa yang harus pekerja terima dari bos (hak), sebagaimana tertuang dalam pasal 54 ayat $1 \mathrm{UU}$ no.13 tahun 2003 bahwa salah satu komponen yang harus

15 Zaeni Asyhadie, "Hukum Kerja: Hukum Ketenagakerjaan Bidang Hubungan Kerja," Jakarta: Raja Grafindo Persada, 2007, 19-20.

${ }^{16}$ Harahap, Hadis-Hadis Ekonomi, 71. 
termuat dalam surat perjanjian kerja adalah besarnya upah dan cara pembayarannya.

Kedua, hak untuk tidak di eksploitir. Tindakan eksploitasi terhadap buruh biasanya dikarenakan paham kapitalisme dari pengusaha yang tumbuh. Mereka merasa bisa bertindak sewenang - wenang terhadap pekerja. Kasus eksploitasi pekerja yang paling banyak terjadi di Indonesia adalah eksploitasi jam kerja. Banyak dari pengusaha yang sewenang-wenang menambah waktu kerja tanpa memperhatikan jam istirahat, bahkan memangkas waktu cuti pekerja. Padahal hal ini sudah di atur dalam UU no.13 tahun 2003 Pasal 79 yang berbunyi "Pengusaha wajib memberi waktu istirahat dan cuti bagi pekerja/buruh", dimana ketentuan waktunya dijelaskan secara terperinci pada ayat 2.

Ketiga, hak atas perlindungan kerja. Selain mendapat hak aecara ekonomi dan pengayoman, pekerja juga berhak mendapat perlindungan kerja dari pengusaha. Setiap pekerja behak mendapat jaminan K3 (Kesehatan dan Keselamatan Kerja) dari perusahaan. Amanah ini tertuang dalam Pasal 86 ayat 1 UU. No.13 tahun 2003, yang berbunyi : "Setiap pekerja/buruh mempunyai hak untuk memperoleh perlindungan atas : a) keselamatan dan kesehatan kerja, b) moral dan kesusilaan, dan c) perlakuan yang sesuai dengan harkat martabat manusia serta nilai-nilai agama". Dengan kata lain, Perusahaan wajib memberikan perlindungan terhadap keberlangsungan hidup para pekerjanya, mencegah mereka dari potensi kecelakaan yang membahayakan nyawa mereka ${ }^{17}$.

\section{Pendekatan Tekstual dalam Studi Islam}

Disebut pendekatan tekstual karena ia menekankan signifikansi teks-teks sebagai sentra kajian Islam dengan merujuk kepada

17 Muhammad Aiz, "Pandangan Hukum Islam Tentang Buruh: Studi Historis di Indonesia," Maslabah (Jurnal Hukum Islam dan Perbankan Syariah) 2, no. 2 (2011): 15. sumber-sumber suci (pristine sources) dalam Islam, terutama al-Qur'an dan Hadits. Pendekatan ini sangat penting ketika kita ingin melihat realitas Islam normatif yang tertulis, baik secara eksplisit maupun implisit, dalam kedua sumber suci di atas. Selain al-Qur'an dan Hadits, kajian tekstual juga tidak menafikan eksistensi teks-teks lainnya sebagaimana ditulis oleh para intelektual dan 'ulama' besar Muslim terdahulu dan kontemporer ${ }^{18}$

Butuh berbagai pendekatan yang diperlukan untuk bisa memahami sebuah fenomena sosial-keagamaan, karena sebuah fenomena bisa dilihat dari banyak sudut pandang. Salah satu perangkat untuk memahami sebuah fenomena sosial-keagamaan adalah Teks suci, dalam hal ini adalah Al-Qur'an dan As-sunnah. Teks merupakan fiksasi atau pelembagaan sebuah wacana lisan dalam bentuk tulisan, Al-Qur'an juga merupakan sebuah teks yang berasal dari Kalamullah yang kemudian dikodifikasi oleh para pelaku sejarah $^{19}$. Al-Qur'an telah menjadi sumber utama eksplorasi hukum umat Islam dalam menghadapi berbagai persoalan, mulai dari teologis, politik, ekonomi, hingga sosial. Untuk memahami Al-Qur'an dibutuhkan ilmu interdisipliner, mulai dari bahasa, sejarah, dan lain sebagainya.

Secara umum, ada 2 pendekatan yang digunakan para mufassir untuk mengimplementasikan Al-Qur'an, yakni pendekatan secara tekstual dan kontekstual. Pendekatan tekstual dalam studi Al-Qur'an dan Tafsir merupakan suatu usaha memahami AlQur'an yang berorientasi pada teks dalam

18 Edi Susanto, Dimensi Studi Islam Kontemporer (Kencana, 2016), 80.

${ }^{19}$ Komaruddin Hidayat, Memahami Bahasa Agama: Sebuah Kajian Hermeneutik (Paramadina, 2016), 132-35. 
dirinya sendiri ${ }^{20}$ Oleh karena itu, wahyu dipahami melalui pendekatan kebahasaanm tanpa melihat latar sosio-historis, kapan, dimana, sebab, dan tujuan wahyu tersebut diturunkan ${ }^{21}$. Sedangkan yang kedua, adalah pendekatan kontekstual adalah memahami teks dengan memperhatikan atau mengkaji keterkaitannya dengan peristiwa atau situasi yang melatar belakangi munculnya teks tersebut atau dengan kata lain, dengan memperhatikan dan mengkaji konteksnya ${ }^{22}$

Jika meminjam istilah fiqhiyah, tafsir tekstual berarti memaknai Al-Qur'an secara lahiriah yang dalam sejarah fiqh dipelopori aliran drabiriah. Dalam memahami AlQur'an,aliran dzabiriah berpegang pada tiga prinsip dasar: pertama, keharusan berpegang teguh pada lahiriah teks dan tidak melampauinya kecuali dengan yang dzahir lainnya atau dengan konsensus ijma' yang pasti. Kedua, maksud teks yang sebenarnya terletak pada yang dzahir, bukan di balik teks yang perlu dicari dengan penalaran mendalam. Demikian pula maslahat yang dikehendaki syara'. Ketiga, mencari sebab di balik penetapan syari'at adalah sebuah kekeliruan ${ }^{23}$

Abdullah Saeed dalam bukunya membagi kaum tekstualis menjadi 2 kelompok, yakni soft textualist dan hard textualist. Kelompok pertama menumpukan makna literal sebagai basis makna teks dan masih menerima peluang model penafsiran lain. sedangkan kelompok kedua memahami makna literal secara rigid tanpa

20 M. Solahudin, "Pendekatan Tekstual dan Kontekstual dalam Penafsiran Al-Quran," Al-Bayan: Jurnal Studi Ilmu Al-Qur'an dan Tafsir 1, no. 2 (2016): 116.

${ }^{21}$ Islah Gusmian, Khazanah Tafsir Indonesia; dari Hermeneutika Hingga Ideologi (Yogyakarta: LKIS Pelangi Aksara, 2013), 248.

${ }^{22}$ Edi Safri, "Metode Memahami Sunnah," Jurnal Ulunnuha 6, no. 1 (2017): 103.

23 Sahiron Syamsuddin and Sahiron Syamsuddin, Hermeneutika Al-Qur'an Mą̧bab Yogya (Islamika, 2003), 171-72.

24 Abdullah Saeed, "Reading the Qur'an in the Twenty-First Century: A Contextualist Approach," Reading the Qur'an in the Twenty-First Century: A Contextualist mempertimbangkan kompleksitas makna ${ }^{24}$. Kelompok kedua didominasi oleh para muslim konservatif yang memiliki kecenderungan menggeneralisir hal-hal yang bersifat spesifik. Al-Qur'an memang bersifat universal, relevan untuk semua jenis waktu, tempat, dan kondisi. Namun, kelompok hard textualist ini memaknai Universalisme Al-Qur'an dengan mendehistorisasi Al-Qur'an itu sendiri, bahkan memandang Al-Qur'an secara ahistori. Menurut mereka meng-historisasi Al-Qur'an berarti menghistorisasi kandungannya dan itu mengurangi karakteristik universalisme AlQur'an, inilah yang membuat mereka enggan meng-kontekstualisasi-kan Al-Qur'an ${ }^{25}$.

Pendekatan Tekstual dalam penafsiran Al-Qur'an maupun As-Sunnah lebih menekankan pada titik-titik gramatikal-tekstual, sehingga pengalaman sosio-historis mufassir tidak punya peranan dalam proses penafsiran ${ }^{26}$. Sehingga dapat kita simpulkan, bahwa bahasa adalah instrumen utama dalam melakukan pengkajian ayat secara tekstual. Metode pendekatan tekstual lebih berpegang pada kaidah al-ibrab bi umum al-lafz la bi kehusus assabab (menumpukan pemahaman pada lafadz secara lebih general dibanding partikularitas sebab). Karena bertumpu pada analisis kebahasaan, tidak jarang tafsir ini sangat kental dengan nalar bayani yang bersifat deduktif, dimana posisi teks Al-Qur'an menjadi dasar penafsiran, dan bahasa menjadi instrumen analisisnya ${ }^{27}$

\footnotetext{
Approach, January 1, 2013, 36, https://doi.org/10.4324/9781315870922.

25 Budi Juliandi and Saifuddin Herlambang, "Menggugat Tafsir Tekstual," At-Tibyan: Jurnal Ilmu AlQur'an dan Tafsir 1, no. 1 (2016): 45.

26 Syahrullah Iskandar, "Studi Al-Quran dan Integrasi Keilmuan: Studi Kasus UIN Sunan Gunung Djati Bandung," Wawasan: Jurnal Ilmiah Agama dan Sosial Budaya 1, no. 1 (2016): 87.

27 Angelika Neuwirth and John Wansbrough, "Quranic Studies. Sources and Methods of Scriptural Interpretation," Welt Des Islams 23 (January 1, 1984): 5758, https://doi.org/10.2307/1570716.
} 
Di antara ciri-ciri metode penafsiran tekstual atau biasa disebut Bil-Ma'tsur atau Tablily, memiliki ciri-ciri diantaranya adalah metode ini banyak melakukan pengkajian nahwiyah atau bacaan yang berbeda-beda (strukturalis). Selain itu, metode ini juga seringkali melakukan tahap pengkajian asal-usul bahasa dengan melansir syair-syair Arab (heruistik dan hermeneutik). Serta banyak mengandalkan cerita atau pendapat sahabat dalam menafsiri makna lafal yang sedang dikaji (riwayat)

Setiap metode atau pendekatan pasti memiliki kelebihan dan kelemahan. Menurut Prof. Dr. Quraish Shihab, Pendekatan tekstual dalam memahami Al-Qur'an juga demikian. Diantara kelebihan metode ini adalah memberikan penekankan terhadap pentingnya bahasa dalam memahami Al-Qur'an, Memaparkan ketelitian redaksi ayat ketika menyampaikan pesan-pesannya, serta Mengikat mufassir dalam bingkai teks ayat-ayat, sehingga membatasinya terjerumus dalam subjektivitas yang berlebihan.

Sedangkan kelemahan pendekatan tekstual, diantaranya adalah terjerumusnya mufassir pada uraian kebahasaan dan kesusastraan yang bertele-tele, sehingga pesan pokok Al-Qur'an menjadi kabur di celah uraian tersebut. Selain itu, seringkali konteks asbabun nu₹ul bisa dikatakan amat sangat terabaikan, seakan-akan ayat tersebut tidak mempunyai ruang histori maupun budaya ${ }^{28}$.

\section{Tafsir dan Mufassir Nusantara}

Penafsiran Al-Quran di Indonesia merupakan salah satu upaya yang dilakukan para cendikiawan Al-Quran untuk memaparkan kandungan ayat - ayat Al-Quran kepada masyarakat Indonesia, baik menggunakan

${ }^{28}$ M. Quraish Shihab, “Membumikan” Al-Quran: Fungsi dan Peran Wabyu dalam Kebidupan Masyarakat (Bandung: Mizan Pustaka, 2007), 84.

${ }^{29}$ Syamsuddin Syamsuddin, "Perkembangan Tafsir Al-Qur'an di Indonesia," Jurnal Ilmiah Islamic Resources 16, no. 1 (2019): 23. bahasa Arab, Indonesia, maupun bahasa Daerah. Perbedaan latar belakang budaya dan bahasa antara Arab dan Indonesia membuat perkembangan Penafsiran Al-Quran di Indonesia mempunyai corak yang berbeda dengan $\mathrm{Arab}^{29}$.

Periodisasi tafsir di Indoneseia secara umum terbagi menjadi 4 periode. Yakni Periode klasik, Periode pertengahan, Periode pramodern, dan Periode modern. Penetpan keempat periode tersebut didasarkan pada ciriciri tafsir yang ada di Indonesia, yang punya perbedaan yang sangat mencolok dengan perkembangan tafsir di Negara-negara $\mathrm{Arab}^{30}$.

Pada periode klasik (Abad ke 7-15 M) penafsiran belum menampakkan bentuk tertentu yang mengacu pada Al-Ma'tsur atau arra'yu larema sifatnya yang masih umum. Pada saat itu Indonesia belum terbentuk komunitas Muslim, masih pada tahap Islamisasi. Pada masa ini tafsir disajikan secara integral bersamaan dengan ilmu lain, seperti Fiqh, Aqidah, dan Tasawuf. Bentuk kajiannya tidak dalam model teoritis-konseptual ${ }^{31}$.

Periode pertengahan (Abad 16-17 M), Tafsir di masa ini sudah mempuyai buku pegangan yang lebih representatif dari ahli Tafsir yang profesional. Diantara upaya penafsirannya adalah dengan memahami tafsir yang berasal dari Timur Tengah yang dibacakan dan diterjemahkan kepada bahasa daerah setempat ${ }^{32}$.

Periode Pramodern (Abad 19 M), pada masa ini muncul ulama-ulama yang mulai menulis Tafsir, kendati karyanya yang lebih populer adalah karya-karya di bidang mistik dan tasawuf. Karya mereka tidak berkontribusi langsung kepada bidang tafsir, tapi ayat-ayat AlQuran seringkali dijadikan dalil untuk

30 Baidan Nashruddin, Perkembangan Tafsir di Indonesia, (Solo: Tiga Serangkai, 2003), 30-38.

${ }^{31}$ Nashruddin, Perkembangan Tafsir, 38.

${ }^{32}$ Ari, "Sejarah Tafsir Nusantara," 119. 
mendukung argumentasi yang mereka ajarkan. Sekilas tafsir pada periode ini tidak mengalami banyak perubahan dari periode pertengahan, namun teknik cara penyampaiannya Nampak lebih maju. Terjmahan yang di masa pertengahan hanya dilakukan secara lisan, kini mulai beralih ke tulis. Demikian pula mulai dilakukan syarh sesuai kebutuhan santri yang mengaji33.

Periode Modern (Abad 20 M), setelah perisitwa sumpah pemuda 1928, yang menyatakan bahwa Bahasa Indonesia adalah Bahasa persatuan, penerjemahan Al-Quran semakin memasuki masa - masa kondusif. Pada tahun tersebut, terbitlah kitab tafsir lokal pertama yakni Al-Furqan. Tahun 1934 terbut Tafsir Hibarna karya Iskandar Idris serta Tafsir Asy-Syamsia karya KH. Sanusi. Tahun 1938 diterbitkan Tarjamat Al-Quran Al-Karim karya dari Mahmud Yunus. Tahun 1942 Mahmud Aziz menulis Tafsir Quran Babasa Indonesia. Kemudian tahun 1953 Zainuddin Hamidi dan Fakhrudin HS menulis Tafsir Al-Quran. Tahun 1966 Hamka menerbitkan karya tafsirnya yang pertama Al-Az̧bar. Disusul Al-Bayan pada tahun 1971, serta Tafsir Al-Quran Al-Madjid AnNur tahun 1973, karya - karya Hamka selalu bergaya bahasa prosa ${ }^{34}$.

Dalam hal metode Tafsir, sistematika penulisan Mufassir Nusantara dapat dibagi menjadi 2. Pertama, Metode tahlili atau runtut adalah penulisan tafsir yang mengacu pada urutan surat yang ada dalam mushaf atau mengacu pada turunnya wahyu. Kenbanyakan tafsir Indonesia menggunakan metode ini, di antaranya Tarjuman al-Mustafid karya Abd Rauf As-sinkili, Tarjamat Al-Qur'an al-Karim karya Mahmud Yunus, Al-Qur'an al-Karim Bacaan Mulya karya H.B Jassin, Quraish Syihab dengan tafsir al-Misbah. Disamping itu, banyak juga tafsir-tafsir dalam bahasa daerah, baik

\footnotetext{
33 Ari, "Sejarah Tafsir Nusantara," 119
}

menggunakan bahasa Jawa, Sumatera maupun bahasa yang ada di Sulawesi menggunakan metode tahlili.

Metode kedua, adalah Metode Maudbu'i. Penulisan dalam tafsir yang menggunakan metode tematik itu baru muncul pada abad ke20, yaitu pada saat dibukanya pasca sarjana pada perguruan tinggi oleh Harun Nasution pada tahun 1982. Diantara tematik klasik adalah Ayat-Ayat Tablil karya Muhammad Quraish Shihab, Edham Syafie ${ }^{\text {ec }}$ dengan karya Tafsir dan Juг, 'Amma.

\section{Analisis Tekstual Ayat-ayat Perlindungan Buruh}

Berikut adalah paparan data dan analisis yang dilakukan peneliti untuk mengetahui relvansi hak-hak buruh dengan teks Al-Quran, beserta pandangan Mufassir Nusantara terhadapnya :

\section{Hak Mendapatkan Upab Yang Layak.}

Sebagaimana dijelaskan pada sub bab sebelumnya, bahwa upah merupakan salah satu hak yang terus diperjuangkan buruh dalam setiap aksinya. Seperti yang telah dikatakan dalam UU no 13 tahun 2003, bahwa upah merupakan salah satu komponen yang harus dicantumkan dalam perjanjian kerja. Pemenuhan janji merupakan perintah yang sangat jelas termaktub dalam surat Al-Maidah ayat 1 :

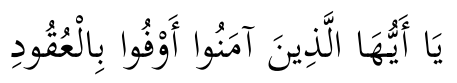

Artinya : "Wahai orang - orang yang beriman, penuhilah janji - janjimu...." (Q.S Al-Maidah : 1)

Ditinjau dari redaksi ayat, ada 2 kata yang menjadi inti dari ayat tersebut yang menjadi dasar dari hak pemberian upah buruh yang أوفو الو أ dan kata العقود. Dalam Mu’jam Al-Lughah Al-

34 Ismail Lubis, Falsifikasi Terjemahan Al-Qur'an Departemen Agama, Edisi 1990 (Yogyakarta: Tiara Wacana Yogya, 2001), 34-36. 
Arabiyah Al-Mu'ashirah Karya Dr. Ahmad Mukhtar Umar, kata أوفو yang berasal dari kata

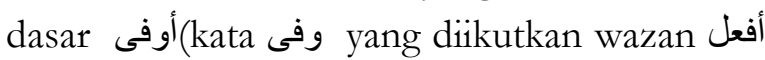
dengan tambahan fungsi اللتعدية) didefinisikan sebagai berikut :

$$
\text { أوفى الوعدَ/ أوفى بالوعد: وفنَ به، أتمّه وأبخزه35 }
$$

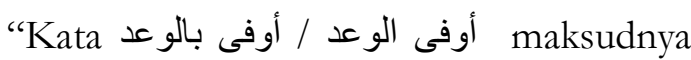
adalah menepati (janji), memenuhinya dan menyelesaikannya". Sedangkan, lafadz العقود merupakan bentuk jamak dari mufrad العقد adapun dalam kamus Taj Al-'Arus karya Mutadha Az-Zabidi, pengertian dari العقد sendiri adalah :

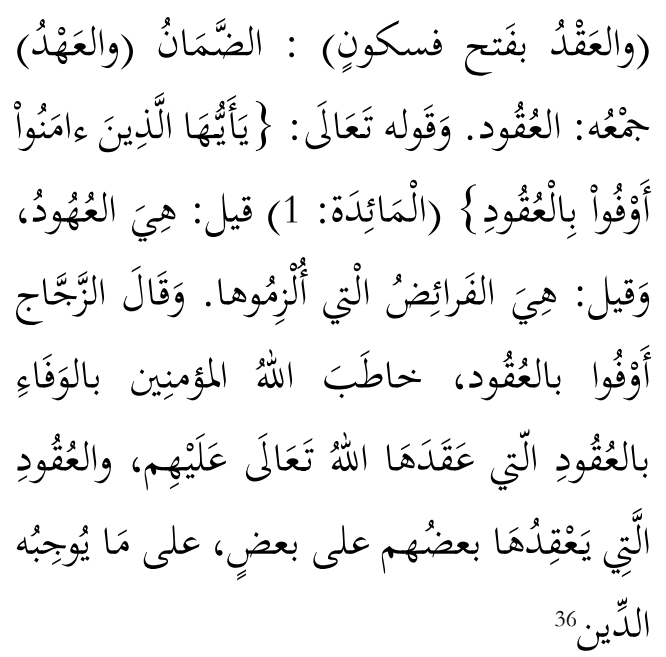

"Lafadz العقد dengan difathah ("Ainnya) lalu disukun (Qafnya) artinya adalah janji (kesepakatan), jamaknya adalah lafadz العقود. Allah berfirman : Wahai orang - orang yang beriman, tepatilah janji - janji kalian (Q.S Al-Maidah : 1). Pendapat lain : maksudnya adalah kesepakatan - kesepakatan. Pendapat lain : kewajiban - kewajiban yang harus أوفوا : أ باعقود maksudnya adalah Allah memerintahkan orang-orang mukmin untuk memenuhi perjanjian mereka

35 Ahmad Mukhtar 'Umar, Mu'jam Al-Lughah Al'Arabiyah Al-Mu'ashirah, Juz 3 ( Al-Qahirah: Dar Al-Fikr, 2008, n.d.), 2475.

${ }^{36}$ Sayyid Muhammad Murtada Al Hasiniy Al Wasiti Al_Zubaydi, Taj al 'Arus Min Jawabir Al Qamus, Juz 8, (AlQahirah: Matba'ah Al Khayriyyahq, 1306), 394. kepada Allah, serta janji - janji mereka satu sama lain (sesama manusia), berdasarkan apa yang telah diwajibkan agama"

Dari penjelasan tekstual diatas, Mufassir Nusantara di antaranya Syaikh Nawawi Al-Jawi, dalam karya fenomenalnya Marah Al-Labid, Syaikh Nawawi Al-Jawi menjelaskan bahwa ia memiliki pemikiran yang selaras dengan analisi teks yang telah disebutkan peneliti di atas. Beliau berpendapat bahwa interaksi sosial merupakan hal yang juga semestinya dijaga menurut ayat diatas,

$$
\begin{aligned}
& \text { وهي جميع ما ألزمه الله تعالى عباده من التكاليف } \\
& \text { والأحكام الدينية، وما يعقدونه فيما بينهم من } \\
& \text { عقود الأمانات والمعاملات ونخوها مما يجب الوفاء } \\
& \text { به أو يحسن ديناج3 }
\end{aligned}
$$

“ العقود yang dimaksud adalah segala sesuatu yang diwajibkan Allah Ta'ala pada hamba - hambanya, berupa tanggung jawab dan hukum - hukum agama. Selain itu, adalah janji - jani hamba terhadap sesamanya, baik berupa amanah, interaksi sosial, dan hal - hal lain yang perlu ditepati, ataupun hal hal yang memperindah kehidupan religi"

Syaikh Nawawi menggunakan terminologi Al-Amanah, Al-Mu'amalat, dan Maa Yajib AlWafa' untuk menggambarkan bahwa janji terhadap sesame manusia juga perlu ditegakkan, tak terkecuali surat perjanjian kerja yang sudah ditanda tangani kedua belah pihak.

Adapun, Prof. Quraish Shihab dalam Tafsirnya Al-Misbah menyatakan bahwa janji dalam ayat ini mengikat 2 belah pihak. Maka

${ }^{37}$ Muhammad bin Umar Nawawi Al Jawi, Marab Labid, Juz 1, (Al-Qahirah: Dar Al Kotob Al-Ilmiyah, 2013), 248. 
dari itu, masing - masing pihak perlu menekan ego demi kepentingan bersama yang sudah disepakati.

"termasuk dalam janji yang harus dipenuhi dalam ayat ini adalah janji yang diucapkan kepada sesama manusia. 'Uqûd (bentuk jamak dari 'aqd ['janji', 'perjanjian']) yang digunakan dalam ayat ini, pada dasarnya berlangsung antara dua pihak. Kata 'aqd itu sendiri mengandung arti 'penguatan', 'pengukuhan', berbeda dengan 'ahd ('janji', 'perjanjian') yang berasal dari satu pihak saja, dan termasuk di dalamnya memenuhi kehendak pribadi. Dengan demikian, dapat dipahami bahwa al-Qur'ân lebih dahulu berbicara mengenai pemenuhan janji daripada undang-undang positif. Ayat ini bersifat umum dan menyeluruh. Sebab, dalam Islam terdapat hukum mengenai dua pihak yang melakukan perjanjian. Tidak ada hukum positif mana pun yang lebih mencakup, lebih jelas dan lebih terperinci daripada ayat ini mengenai pentingnya memenuhai dan menghormati janji" 38

Dengan demikian, penjelasan ini selaras dengan penjelasan Syaikh Nawawi Al-Jawi maupun tinjauan teks yang dilakukan peneliti melalui beberapa kamus sebelumnya.

Sedangkan KH. Bisri Musthofa berpendapat bahwa janji adalah kewajiban yang harus ditunaikan layaknya hutang. Dalam karyanya Al-Ibriz, beliau mengemukakan :

"He wong-wong mukmin! Sira kabeh supaya pada netepi perjanjian (Ategese netepi kuwajiban $)^{39}$ "(Wahai orang - orang mukimin! hendaknya kalian menepati perjanjian -maksudnya kewajiban kalian)

Dengan demikian, penafsiran Mufassir nusantara terhadap surat Al-Maidah ayat 1

38 "Surat Al-Ma'idah Ayat 1," Tafsir AlQuran Online, accessed December 26, 2020, https://tafsirq.com/permalink/ayat/670. mempunyai relevansi yang akurat dengan tinjauan tekstual ayat melalui data yang dikumpulkan dari kamus - kamus terminologi Arab. Pada intinya, Mufassir Nusantara mendukung pemenuhan perjanjian kontrak kerja yang dilakukan pihak pemilik usaha dengan pekerja, karena sesuai dengan apa yang termaktub dalam Al-Quran secara tekstual.

\section{Hak Untuk Tidak Dieksploitir.}

Eksploitasi di kalangan pekerja seringkali terjadi karena adanya bibit - bibit kapitalisme dalam jiwa pemilik usaha. Harta dan power membuat mereka merasa punya kuasa yang lebih terhadap pekerjanya. Di sisi lain, pekerja ketakutan karena khawatir akan nasib karirnya. Padahal tindakan ini benar - benar ditentang dalam Al-Quran. Firman Allah surat Al-'Alaq ayat 6-8 :

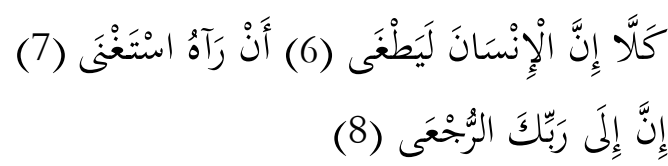

benar-benar melampaui batas (6)

Karena dia melihat dirinya serba cukup. (7) Sesungguhnya Hanya kepada Tuhanmulah kamu kembali (7)" (Q.S Al-'Alaq : 6-8)

Ayat diatas memberikan isyarat pada pemahaman kapitalis dengan 2 kosakata yang sangat berhubungan erat dengan kapitalisme. Yakni kata بطغى dan بطغى kata استغنى sendiri merupakan bentuk mudhari' dari madhi طغى. Definisnya sebagaimana ditulis dalam Mu'jam Al-Wasith buah karya Badan Bahasa Arab Kairo, adalah sebagai berikut :

$$
\text { (طَغى) طغيا وطغيانا جَاوز الحَد المقبول40 }
$$

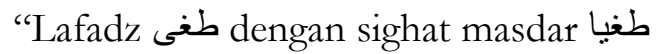
dan طغيانا artinya adalah melampaui batas wajar"

${ }^{39}$ Bisri Mustofa, Al-Ibriz: Limakrifati Tafsir Al-Al Qur'an Al-Azis Billughoh Al-Jawiyah, Juz 6 (Solo: Lembaga Kajian Strategis Indonesia, 2015), 269.

${ }^{40}$ Ibrahim Anis, Al-Mu'jam Al-W asith (Al-Qahirah: Maktabah Al-Shuruq Al-Dauliyah, 2004), 558. 
Melampaui batas wajar artinya sewenang wenang, atau keterlaluan dalam bersikap. Hadirnya sikap طنى ini didukung kepribadian manusa yang استغنى استغنى Lafadz. استى sendiri merupakan bentuk mazid sudasi dari akar kata استفعل yang kemudian diikutkan wazan غني dengan membawa faidah للطلب. adapun, lafadz استغنى ini menurut Dr. Mukhtar Umar dalam Mu'jamnya didefinisikan sebagai :

$$
\begin{aligned}
& \text { استغنى فلانُ: (1) وفُر مالُه وكثُر، صار ثَرِيَّا "زادت }
\end{aligned}
$$

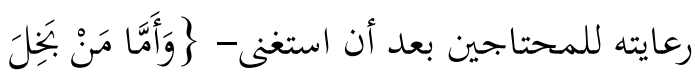

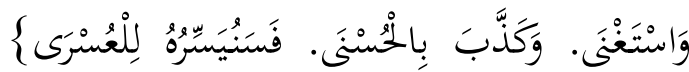

$$
\begin{aligned}
& \text { " ترفّع عن طلب العون }
\end{aligned}
$$

“Lafadz استغنى فلان, artinya (1) hartanya melimpah dan bergelimang, jadi miliarder. Contoh : Pengayomannya terhadap orang - orang yang membutuhkan kini bertambah semenjak ia bergelimang harta. Allah berfirman : adapun orang - orang yang pelit dan merasa cukup (dengan hartanya yang melimpah), serta mendustakan pahala yang baik, maka kelak kami siapkan untuknya (jalan) yang sulit.(2) tidak mau memohon pertolongan (Allah)"

Merasa cukup sehingga bersikap sewenang-wenang, adalah 2 sikap yang tak selayaknya dilakukan kepada sesama manusia. Pekerja juga manusia, maka sudah sepantasnyalah para pengusaha berbuat manusiawi terhadap para pekerjanya. Dalam ayat pertama, sifat kesewenang - wenangan manusia ini diperkuat menjadi Kalam Inkari atau dalam kajian balaghah merupakan istilah bagi sebuah kalimat yang memiliki 2 perangkat emphasis.

Dari kacamata Mufassir Nusantara, berikut adalah pemaparan mereka soal surat Al-Alaq

41 'Umar, Mu'jam Al-Lughah Al-'Arabiyah AlMu'ashirah, 1646.

${ }^{42}$ Jawi, Marah Labid, 647. ayat 6-8 ini oleh Syaikh Nawawi Al-Jawi. Menurut beliau, faktor utama timbulnya rasa kesewenang-wenangan adalah kekuatan finansial yang lebih kuat disbanding dengan orang-orang di sekitarnya. Mereka menganggap harta bisa dijadikan sumber kekuatan mereka untuk menindas, atau setidaknya memberikan perasaan intimidatif kepada orang - orang di sekitarnya.

Dalam tafsirnya, Syaikh Nawawi memberikan penjelasan bahwa penyebab keangkuhan Abu Jahal yang diceritakan AlQuran di surat Al-'Alaq ayat 6 sampai terakhir adalah sebab kebanggaannya terhadap kemampuan finansialnya.

$$
\begin{aligned}
& \text { أي حقا يا محمد إن الكافر يتكبر على ربه لأن } \\
& \text { رأى نفسه مستغنيا عن الله بالمال نزلت الأية من } \\
& \text { ههنا إلى آخر السورة في أبي جهل } 42
\end{aligned}
$$

Senada dengan pendapat Syaikh Nawawi, Prof Quraish Shihab juga mengemukakan bahwa rasa memiliki terhadap harta merupakan asal munculnya sifat congkak terhadap kuasa Allah SW'T.

"Sesungguhnya manusia suka melampaui batas dan sombong di hadapan Tuhannya, karena ia memandang dirinya memiliki kekayaan dan harta"43.

Dalam penafsiran diatas, Prof. Quraish Shihab menyebutkan, bahwa titik masalahnya adalah di rasa memilikinya. Pada dasarnya, sebagai hamba hendaknya kita memahami bahwa segala yang kita miliki adalah milik

\footnotetext{
43 "Surat Al-'Alaq Ayat 6," Tafsir Al-Quran Online, accessed December 26, 2020, https://tafsirq.com/permalink/ayat/6112.
} 
Tuhan, sebagaimana yang difirmankan Allah di surat Al-'Alaq ayat 8.

Dalam Al-Ibriz, Kiai Bisri memberikan responnya terhadap ayat ini secara langsung,

"Abu Jahal Iku banget olehe kurang ajar, ngendel-ngendelaken bandane. Yen guneman angger mangap bae. Kanda-kanda jare yen kanjeng nabi arep diideki janggane, lan liyaliyane maneh guneman kang lacut. Nuli Allah nurunake ayat iki : Temenan, sakbenere menuso (sing kaya Abu jahal) iku banget lacute. Deweke ngendel-ngendelake bandane ${ }^{44}$.

(Abu Jahal itu kelewat kurang ajar, mengagung-agungkan kekayaannya, berbicara semaunya, menyatakan bahwa akan menginjak leher Nabi, dan perkataan - perkataan buruk lainnya. Maka Allah menurukan ayat ini : Sungguh, pada dasarnya manusia (yang seperti Abu Jahal) itu kelewat kurang ajar. Ia menuhankan harta bendanya)

Dalam hal ini, Beliau secara argumentasi beliau memiliki pandangan yang sama dengan Syaikh Nawawi, maupun Prof. Quraish. Namun yang berbeda adalah gaya bahasa yang disampaikan. Kiai Bisri memberikan intrik emosional dalam penafsirannya sehingga pembaca merasa mendapatkan pengalaman spiritual maupun emosional yang lebih

Dari 3 pendapat diatas, dapat disimpulkan bahwa argument para Mufassir Nusantara ini masih punya relevansi yang cukup kuat dengan analisis ayat ini secara tekstual. Bahwa kesewenang-wenangan datang dari rasa memiliki kekuatan yang lebih dibanding yang lainnya. Dalam bidang pekerjaan pun demikian, bos bukan berarti punya hak seluas-luasnya atas pekerja, semua masih punya batas koridornya masing-masing.

\section{Hak Perlindungan Kerja}

Sebagaimana dijelaskan sebelumnya, bahwa perlindungan terhadap pekerja dijamin oleh Pasal 86 ayat 1 UU. No.13 tahun 2003. Hal ini didukung pula dengan keberadaan Islam yang menjunjung tinggi nilai - nilai kemanusiaan. Islam muncul dan berkembang di era yang penuh dengan ketidak adilan, kezaliman, dan kegelapan. Sehingga tak mengherankan bila Islam menjadi pilihan yang tepat saat itu bagi masyarakat Hijaz. Al-Quran sendiri mengusung nilai - nilai kemanusiaan dalam ayat-ayatnya :

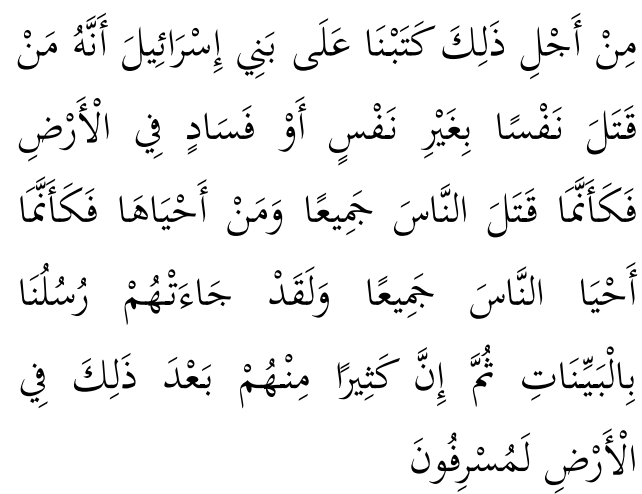

Artinya : "Oleh Karena itu kami tetapkan (suatu bukum) bagi Bani Israil, babwa: barangsiapa yang membunuh seorang manusia, bukan Karena orang itu (membunub) orang lain, atau bukan Karena membuat kerusakan dimuka bumi, Maka seakan-akan dia Telah membunuh manusia selurubnya. dan barangsiapa yang memelihara kebidupan seorang manusia, Maka seolaholab dia Telab memelihara kebidupan manusia semuanya. dan Sesunggubnya Telah datang kepada mereka rasul-rasul kami dengan (membawa) keterangan-keterangan yang jelas, Kemudian banyak diantara mereka sesudah itu sunggub-sungguh melampani batas dalam berbuat kerusakan dimuka bumi" (Q.S Al-Maidah : 32)

Konsern utama ayat diatas dalam pembahasan hak perlindungan buruh adalah pada lafadz أحيا. Ayat ini bersifat persuasive, mengajak kepada umat Islam pada umumnya, termasuk para pengusaha untuk melindungi nyawa saudara sesame manusianya. Dengan iming-iming pahala yang begitu besar. Lafadz sendiri merupakan bentuk Mazid Ruba'i

${ }^{44}$ Mustofa, Al Ibriz, 2249. 
dari bentuk Mujarrad حي yang artinya hidup ${ }^{45}$, diikutkan wazan أفعل dengan membawa faidah للتعدية, Dr. Ahmad Mukhtar Umar mendefinisikannya sebagai berikut :

$$
\begin{aligned}
& \text { أحيا يُهِيى، أَحْي، إحْياءً، فهو تُحي، والمفعول }
\end{aligned}
$$

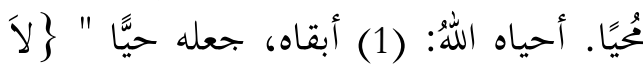

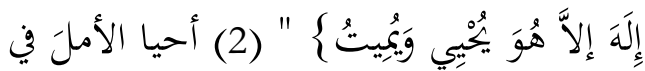

$$
\begin{aligned}
& \text { نفوسهم: جدّده. }
\end{aligned}
$$

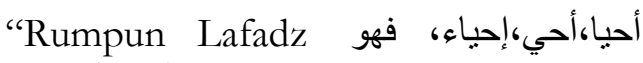
محي، و المفعول محيا. Contoh kalimat (1) Allah menjadikannya hidup (Tiada tuhan kecuali Dia yang Maha Menhidupkan dan Maha Mematikan). memperbarui harapan pada diri mereka. (3) memperbaiki"

Dari penjelasan diatas, bisa diambil sebuah titik terang bahwa أحيا الناس adalah memperbaiki kehidupan manusia, baik secara agama, ekonomi, maupun sosial. Membantu manusia untuk tetap hidup dan menjalankan tugasnya sebagai khalifatullah fil Ard.

Hal senada diungkapkan oleh para Mufassir Nusantara Syaikh Nawawi Al-Jawi. Menurut beliau, yang dimaksud 'menghidupkan' disini bukanlah seperti kuasa Allah atas anugerah mukjizat Nabi Musa. Namun yang dimaksud adalah upaya-upaya melestarikan kehidupan. Yakni dengan menjaga dan menyelamatkan ekosistem sekitar.

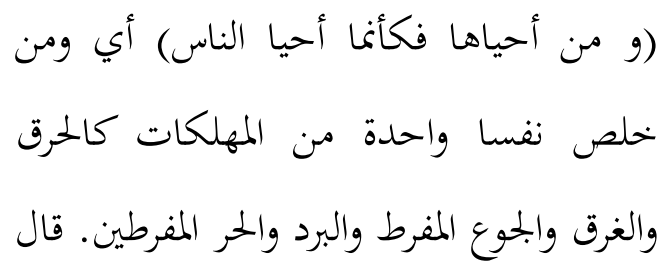

45 Muhammad Yunus, Kamus Arab Indonesia (Jakarta: Fokusmedia dan Citra Harta Prima, 2011), 101.

46 'Umar, Mu'jam Al-Lughab Al-'Arabiyah AlMu'ashirah, 597.

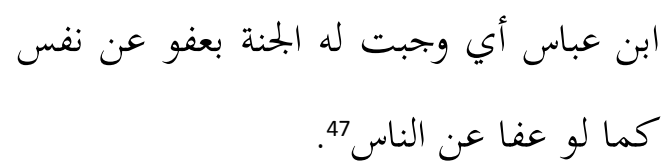

"(dan barangsiapa menghidupi satu nyawa, maka ia seakan menghidupi seluruh manusia) maksudnya, barangsiapa menyelamatkan satu nyawa dari sebuah kerusakan seperti terbakar, tenggelam, kelaparan parah, serta hawa panas dan dingin yang sangat parah (maka ia mendapat pahala layaknya menyelamatkan seluruh manusia). Ibnu Abbas pernah berkata : Maksudnya, ia berhak mendapat surga atas sikap kasihnya terhadap sebuah nyawa, sebagaimana Allah melimpahkan kasih pada manusia"

Tindakan- tindakan yang dilakukan manusia untuk menjaga keselamatan jiwa manusia yang lain adalah ibadah yang mempunyai potensi pahala yang besar, sebagaimana menghilangkan nyawa juga berdampak sangat buruk dari sisi teologis.

Dalam Al-Misbah, Prof. Quraish mengemukakan penafsirannya atas ayat ini sebagai sisi keadilan dalam Islam, yakni antara sisi kriminal dan kebaikan yang sama - sama punya dampak yang serius, baik dalam peradaban manusia maupun reputasi agama.

"Ayat di atas mengandung dua makna yang menerangkan bahwa Islam telah memelihara undang-undang dalam suatu masyarakat dan dasar tolong menolong sesama individu dan masyarakat. Dengan kata lain, Islam telah memelihara keselamatan, keamanan dan tolong menolong antara individu dan masyarakat". ${ }^{48}$

Islam menjamin pemeluknya, bahwa Islam adalah agama kedamaian yang menjunjung tinggi nilai-nilai kemanusiaan. Namun itu bukan berarti orang-orang berpangku tangan dan

47 Jawi, Marah Labid, 260.

48 "Surat Al-Ma'idah Ayat 32," Tafsir Al-Quran Online, accessed December 26, 2020, https://tafsirq.com/permalink/ayat/701. 
menjadikan agama sebagai kambing hitam jika terjadi kasus kriminal. Agama dan pemeluknya adalah 2 sisi mata uang yang tak bisa dipisahkan.

Sedangkan, Kiai Bisri menafsirkan, bahwa menjaga kehidupan adalah mampu mengendalikan emosi. Ini sangat penting dilakukan, karena sebagai dampak dari penjelasan awal bahwa pembunuhan sangat dikutuk dalam agama. Maka upaya preventif untuk menghindari aksi pembunuhan adalah menahan emosi, sabar, dan berpikir panjang.

\section{"Lan sing sopo wonge nguripi (ora mateni), Ateges nguripi menuso kabeh" ${ }^{49}$ " \\ (dan barangsiapa yang menghidupi (tidak membunuh), seakan ia menghidupi semua manusia)}

Dalam penafsirannya diatas, Kiai Bisri memaknai menghidupi dengan tidak membunuh, tentu hal ini juga masih punya korelasi dengan penjelasan Syaikh Nawawi maupun Prof. Quraish. Kiai Bisri lebih fokus pada menekan angka pembunuhannya, sedangkan Syaikh Nawawi dan Prof. Quraish pada peningkatan kesejahteraan.

Dari ketiga pendapat diatas, dapat diambil simpulan bahwa menjaga kelestarian hidup manusia adalah kewajiban masing - masing individu. Demikian pula dalam hal pekerjaan. Pimpinan harus memastikan perusahaannya tanggap terhadap hak perlindungan kerja para karyawannya.

\section{Kesimpulan}

Al-Quran mendukung semesta perjuangan buruh terhadap hak - haknya. Hak - hak buruh yang tertera dalam UU no.13 tahun 2003 punya korelasi yang kuat dengan ayat - ayat Al-Quran. Suara buruh punya intertekstualitas terhadap teks - teks Al-Quran. Yakni hak atas upah yang layak di surat Al-Maidah ayat 1 , hak tidak di eksploitir di surat Al-'Alaq ayat 6-8, dan hak perlindungan kerja di surat Al-Maidah ayat 32.
Mufassir Nusantara sebagai mediator antara $\mathrm{Al}-\mathrm{Quran}$ dengan masyarakat punya peranan yang penting dalam memberikan penjelasan sejelas-jelasnya kepada masyarakat awam. Para Mufassirini, dalam hal ini adalah Syaikh Nawawi Al-Jawi, Prof. Quraish Shihab, dan KH. Bisri Mustofa. Pendapat yang mereka kemukakan dalam karya tafsir mereka punya relevansi yang cukup akurat dengan analisis leksikon dan gramatikal yang terdapat pada 3 ayat di atas. Ini menunjukkan kepekaan Mufassir nusantara dalam kepakaran linguistik Arab merupakan modal yang sangat penting untuk menafsirkan Al-Quran dengan citarasa lokal yang mereka bawa.

\section{Daftar Kepustakaan}

Adz-Dzahabi, Muhammad Husain. At-Tafsir wa Al-Mufassirun, Juz I., Beirut: Dar AlFikr, 2000.

Aiz, Muhammad. "Pandangan Hukum Islam Tentang Buruh: Studi Historis di Indonesia." Maslahah Jurnal Hukum Islam dan Perbankan Syariab) 2, no. 2 (2011): 1-17.

Al-Jawi, Muhammad bin Umar Nawawi. Marah Labid, Juz 1. Al-Qahirah: Dar Al-Kotob Al-Ilmiyah, 2013.

Al-Zubaydi, Sayyid Muhammad Murtada Al Hasiniy al Wasiti. Taj Al-'Arus min Jawabir Al-Qamus. Al-Qahirah: Matba'ah Al-Khayriyyahq, 1306.

Anis, Ibrahim. Al-Mu'jam Al-Wasith. AlQahirah: Maktabah Al-shuruq AlDauliyah. 2004.

Ari, Anggi Wahyu Wahyu. "Sejarah Tafsir Nusantara." Jurnal Studi Agama 3, no. 2 (2019).

Asyhadie, Zaeni. Hukum Kerja: Hukum Ketenagakerjaan Bidang Hubungan Kerja. Jakarta: Raja Grafindo Persada, 2007.

Gusmian, Islah. Khazanah Tafsir Indonesia; dari Hermeneutika Hingga Ideologi. Yogyakarta: LKIS Pelangi Aksara, 2013.

\footnotetext{
${ }^{49}$ Mustofa, Al-Ibriz, 286.
} 
Harahap, Isnaini. Hadis-Hadis Ekonomi. Jakarta: Prenada Media, 2017.

Hendrastomo, Grendi. "Menakar Kesejahteraan Buruh: Memperjuangkan Kesejahteraan Buruh diantara Kepentingan Negara dan Korporasi." Jurnal Informasi 16, no. 2 (2010): 1-16.

Hidayat, Komaruddin. Memahami Bahasa Agama: Sebuab Kajian Hermeneutik. Jakarta: Paramadina, 2016.

Iskandar, Syahrullah. "Studi Al-Quran dan Integrasi Keilmuan: Studi Kasus UIN Sunan Gunung Djati Bandung." Wawasan: Jurnal Ilmiah Agama dan Sosial Budaya 1, no. 1 (2016): 86-93.

Juliandi, Budi, and Saifuddin Herlambang. "Menggugat Tafsir Tekstual." AtTibyan: Jurnal Ilmu Al-Qur'an dan Tafsir 1, no. 1 (2016): 45-69.

Lubis, Ismail. Falsifikasi Terjemahan Al-Qur'an Departemen Agama, Edisi 1990. Yogyakarta: Tiara Wacana Yogya, 2001.

Mirzaqon T, Abdi. "Studi Kepustakaan Mengenai Landasan Teori dan Praktik Konseling Expressive Writing." Jurnal BK Unesa 8, no. 1 (2017).

Mubin, Fatkhul. "Tafsir Emansipatoris: Pembumian Metodologi Tafsir Pembebasan." Mumtaæ: Jurnal Studi AlQuran dan Keislaman 3, no. 1 (2019): 131-51.

Mustofa, Bisri. Al-Ibriz: Limakrifati Tafsir AlQur'an Al-Azis Billughoh Al-Jawiyah. Solo: Lembaga Kajian Strategis Indonesia, 2015.

Nashruddin, Baidan. Perkembangan Tafsir di Indonesia. Solo: Tiga Serangkai, 2003.

Neuwirth, Angelika, and John Wansbrough. "Quranic Studies. Sources and Methods of Scriptural Interpretation." Welt Des Islams 23 (January 1, 1984). https://doi.org/10.2307/1570716.

Pratiwi, Dessy Fitri, Hadiyanto A. Rachim, and Rudi Saprudin Darwis. "Keberfungsian Sosial Buruh Perempuan pada Sektor
Industri dalam Keluarga." Prosiding Penelitian dan Pengabdian Kepada Masyarakat 2, no. 2 (2015).

Qomar, Moh Nurul. "Kritik Karl Marx Terhadap Konsep Buruh Kapitalis Kajian Komparatif Ekonomi Syariah Atas Buku Das Kapital I." In Proceedings of Annual Conference for Muslim Scholars, 3:1003-9, 2019.

Riyadi, Fuad. "Sistem dan Strategi Pengupahan Perspektif Islam." Iqtishadia 8, no. 1 (2015).

Saeed, Abdullah. "Reading the Qur'an in the Twenty-First Century: A Contextualist Approach." Reading the Qur'an in the Twenty-First Century: A Contextualist Approach, January 1, 2013, 1-200. https://doi.org/10.4324/97813158709 22.

Safri, Edi. "Metode Memahami Sunnah." Jurnal Ulunnuba 6, no. 1 (2017): 1-10.

Shihab, M. Quraish. "Membumikan" Al-Quran: Fungsi dan Peran Wabyu dalam Kehidupan Masyarakat. Bandung: Mizan Pustaka, 2007.

. Kaidah Tafsir. Jakarta: Lentera Hati Group, 2013.

Solahudin, M. "Pendekatan Tekstual dan Kontekstual dalam Penafsiran Alquran." Al-Bayan: Jurnal Studi Ilmu AlQur'an dan Tafsir 1, no. 2 (2016): 11530.

Susanto, Edi. Dimensi Studi Islam Kontemporer. Yogyakarta: Kencana, 2016.

Syamsuddin, Sahiron, and Sahiron Syamsuddin. Hermeneutika Al-Qur'an Mąhab Yogya. Islamika, 2003.

Syamsuddin, Syamsuddin. "Perkembangan Tafsir Al-Qur'an di Indonesia." Jurnal Ilmiah Islamic Resources 16, no. 1 (2019).

Tim Penyusun. UU No 13 Tabun 2003 tentang Ketenagakerjaan. Jakarta: Media Press, 2005.

Umar, Ahmad Mukhtar. Mu'jam Al-Lughah Al'Arabiyah al-Mu'ashirah, Juг 3. AlQahirah: Dar Al-Fikr, 2008. 
Yunus, Muhammad. Kamus Arab Indonesia. Jakarta: Fokusmedia dan Citra Harta Prima, 2011.

Referensi lain

“KBBI Daring.” Accessed December 26, 2020. https://kbbi.kemdikbud.go.id/Error.h tm? aspxerrorpath $=/$ entri $/$ buru

Tafsir AlQuran Online. "Surat Al-'Alaq Ayat 6." Accessed December 26, 2020. https://tafsirq.com/permalink/ayat/6 11
Tafsir AlQuran Online. "Surat Al-Ma'idah Ayat 1." Accessed December 26, 2020. https://tafsirq.com/permalink/ayat/6 70.

Tafsir AlQuran Online. "Surat Al-Ma'idah Ayat 32." Accessed December 26, 2020. https://tafsirq.com/permalink/ayat/7 01

Yasmin, Aisha Amelia, Ika Krismantari, and Nashya Tamra. "Kasus Aice: Dilema Buruh Perepuan Di Indonesia Dan Pentingnya Kesetaraan Gender Di Lingkungan Kerja." The Conversation. Accessed December 26, 2020. 